\title{
Joanna Bator w polskim polu literackim
}

\begin{abstract}
Kocznur Agnieszka, Joanna Bator w polskim polu literackim [Joanna Bator in the Polish Literary Field]. „Przestrzenie Teorii” 35. Poznań 2021, Adam Mickiewicz University Press, pp. 247-261. ISSN 1644-6763. DOI 10.14746/pt.2021.35.12.
\end{abstract}

The starting point of the article is locating Joanna Bator in the Polish literary field using Pierre Bourdieu's methodology, and considering such elements as gender determinants, the author's attitude towards the media and self-creation, and the time of the prose's debut. The Nike Prize Bator was awarded in 2013, and not only did enable this author to maintain autonomy in her field, but also led to a change in poetics, i.e. a change in the dominant genre of her novel from magical realism to fairy tale. The article describes the conditions that influenced the transfer of the author by critics from the current of high and award-winning literature to the prose of the medium.

KEYWORDS: Joanna Bator, feminism, Nike prize, literary field

\section{Płeć Nike}

Otrzymanie najważniejszego wyróżnienia zawsze wiąże się ze zmianą statusu i nieodwracalnościa, czego świadomość mają piszący. Joanna Bator otrzymała je w roku 2013 za Ciemno, prawie noc, jako piąta z sześciu dotychczas nagrodzonych tą literacką nagrodą kobiet. - „Kiedy odbierałam Nike, myślałam już o nowej książce. I o tym, że mam za sobą ostateczny

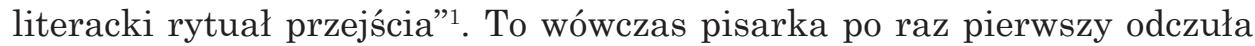
kryzys twórczy².

W tej i innych wypowiedziach autorki poza niemocą twórczą wyraźnie rozbrzmiewa coś jeszcze - presja ze strony środowiska literackiego. Niebezzasadnym wobec tego będzie stwierdzenie, że w momencie uporania się z kryzysem osobistym, pisarce udało się również wyzwolić ze społecznych oczekiwań w stosunku do jej pisania. Z cała świadomością autokreacji, a co za nią idzie - nieliterackiej strategii wydawniczej, jaka pojawia się w ówcze-

${ }^{1}$ Światynia Nike. Wywiad z Joanna Bator, [w:] Rozmowy z autorami - lubimyczytac. $p l$, pod red. D. Warszawskiego, J. Janowicz, <https://issuu.com/lubimyczytac.pl/docs/rozmowy_z_autorami_-_lubimyczytac.p> [dostęp: 5.06.2019].

${ }^{2}$ „Wydałam tę powieść w listopadzie 2012 roku i do lipca 2013 nie napisałam zdania wartego uwagi. Nic. To był czarny, przerażający czas. Ile było takich świetnie zaczętych karier...? Już sobie wyobrażałam, jak Przemysław Czapiński pisze »kariera zakończona ostatnią niezła powieścią w 2012«, ukoronowaniem... a ileż było takich karier, które kończyły się jakimś rodzajem uznania i później - nic”. K. Marcysiak, Kultowe rozmowy: Joanna Bator, <https://www.youtube.com/watch?v=3HY5GH8HAm8> [dostęp: 5.01.2019]. 
snych wywiadach, zakładam, że to właśnie wyzwolenie się z tych oczekiwań wywołało zmianę strategii pisarskiej i skupienie się na autokreacji. Status ontologiczny Joanny Bator w polu literackim określiłabym słowami Piotrusia Pana: między i pomiędzy. To specyficzne umiejscowienie wynika z kilku czynników: płci ${ }^{4}$, statusu ekonomicznego, kapitału kulturowego, momentu debiutu, stosunku do mediów i stosunku do autokreacji.

$\mathrm{W}$ polskim polu literackim utrzymywanie się z pisania literatury jest bardzo trudne - udaje się to zaledwie kilkunastu osobom w kraju ${ }^{5}$. Otrzymanie nagrody literackiej bywa często momentem przełomowym, który poszerza skalę możliwości o łatwy dostęp do instytucji wydawniczych i mediów, a także niemal zawsze gwarantuje więcej zamówień literackich i nieliterackich $^{6}$. Nagrodę Literacką Nike uznaje się powszechnie za najważniejsza i najbardziej wpływową polską nagrodę literacka, określając ją mianem „polskiego Nobla”. Odsłania pole literackie, ale też je konstytuuje.

Nagroda ta przyznawana jest od roku 1997 przez "Gazetę Wyborczą" i Fundację Agora ${ }^{7}$, a jej celem jest promocja polskiej literatury współczesnej, ze szczególnym uwzględnieniem powieści. W maju 1996 roku, gdy powstanie nagrody zostało ogłoszone, wywołało to niemały wstrzas w polskim życiu literackim. Akcja promocyjna nagrody, obejmowała ogłoszenie listy 20 kandydatów/-ek podczas Targów Książki w Warszawie, a same nominowane książki wraz z sylwetkami osób je piszących, były odtąd cotygodniowo prezentowane prasie. Co więcej, finałowa siódemka została ogłoszona podczas Targów Książki w Krakowie, a wydarzeniu temu towarzyszyły audycje radiowe, wywiady, artykuły prasowe i spotkania telewizyjne z nominowanymi. Nagroda odtąd przyznawana jest zawsze według tzw. wzorca bookerowskiego (przekopiowanego z kolej z gali oscarowej) ${ }^{8}$, a uroczystość transmitowana przez telewizję publiczna. Dodatkowo, aby zaangażować czytelników w proces wyboru laureatów, utworzono drugą nagrodę - Nike Czytelników. Jej laureat otrzymuje jednak jedynie nagrodę posiadająca

${ }^{3}$ J.M. Barrie, Piotruś Pan w Ogrodach Kensingtońskich, przeł. A. Wieczorkiewicz, Poznań 2018.

${ }^{4}$ Odczytywanie nagród przez płeć nie jest ujęciem nowym - odsyłam do szeroko zakrojonych badań tzw. gender bias w odniesieniu do Nagrody Nobla przeprowadzonych np. przez P. Lunnemann, M.H. Jensen i L. Jaufredd, opublikowanych w „Humanities \& Social Sciences Communication" 2019, nr 5, <https://www.nature.com/articles/s41599-019-0256-3> [dostęp: 30.04.2021].

${ }^{5}$ G. Jankowicz i in., Literatura polska po 1989 roku w świetle teorii Pierre'a Bourdieu. Raport $z$ badań, Kraków 2014, s. 40.

${ }^{6}$ Tamże.

${ }^{7}$ Oficjalna strona internetowa Nagrody Nike, http://nike.org.pl/ [dostęp: 3.05.2019].

${ }^{8}$ P. Czapliński, Przedmowa do polskiego wydania, [w:] J.F. English, Ekonomia prestizu, przeł. P. Czapliński, Ł. Zaremba, Warszawa 2013, s. 12. 
kapitał symboliczny - złote pióro. Jednym z głównych zarzutów wobec nagrody, który powtarza się od początku jej istnienia jest antypragmatyczna rozległość obejmowanego obszaru9. Tj. wyłanianie zwycięskiej „najpiękniejszej książki roku" spośród poezji, prozy, eseju, dramatu i wszystkich gatunków pobocznych.

Laureaci, poza pieniędzmi (obecnie - sto tys. zł) i statuetką zaprojektowana przez Gustawa Zemłę, corocznie mogą liczyć na zainteresowanie mainstreamowych mediów i wielokrotny wzrost sprzedaży książek, których nabywcami są również osoby zazwyczaj niezainteresowane literatura. Nike sama w sobie stanowi rekomendację ze względu na swój prestiż. Medialność tej nagrody jest nieporównywalna z żadnym innym polskim wydarzeniem literackim. Równocześnie ze względu na zmieniające się, lecz często złożone ze znanych osób zajmujących się literatura, krytyką literacką, dziennikarstwem jury, uznaje się ją za jedną z najważniejszych w Polsce, a jej otrzymanie równoznaczne jest zarówno z docenieniem wybitnej książki, jak i zazwyczaj z ukonstytuowaniem tej pozycji w kanonie. Nagroda ta, mówiąc językiem Bourdieu, porządkuje i wprowadza hierarchię w polu literackim, a osobami nagrodzonymi zostaja zazwyczaj twórcy i twórczynie z istniejacym dorobkiem pisarskim (wyjątkami są dwie kobiety - Dorota Masłowska i Bronka Nowicka i jeden mężczyzna - Wojciech Kuczok). Powoduje ona konwersję kapitału: symbolicznego, reprezentowanego przez dzieło, i ekonomicznego, który stanowi jej pieniężna wysokość. Przyznanie nagrody jest więc aktem przełożenia jednego kapitału na drugi ${ }^{10}$.

Decyzja o przyznaniu Nike danemu pisarzowi czy pisarce nigdy nie pozostaje bez echa - wpływa nie tylko na zwiększenie jednostkowego kapitału danej osoby piszaccej, ale również na cały obieg wydawniczy. Nagrodę tę, ze względu na jej zakres i zasięg, można odbierać również w kategoriach polityczności - analizując wybory jury i czytelników począwszy od ustanowienia nagrody, bez trudu da się zauważyć ilościową różnicę genderowa. Nagrodę przyznano dotychczas 20 razy, werdyktem jury otrzymało ją pięć kobiet: Joanna Olczak-Ronikier (2002), Dorota Masłowska (2006), Olga Tokarczuk (2008 i 2015), Joanna Bator (2013) i Bronka Nowicka (2016). Prześledziwszy kariery literackie nagrodzonych kobiet, trudno nie odnieść wrażenia, że część z nich wypadła z obiegu literackiego, mimo otrzymania nagrody, a mowa tu o Joannie Olczak-Ronikier i Bronce Nowickiej. W przypadku tej drugiej sprawa jest o tyle skomplikowana, że nagrodzona została poezja, która funkcjonuje we własnym, niezwykle niszowym obiegu, opierającym się niemal wyłącznie na kapitale symbolicznym. Nike Czytelników przyznano

\footnotetext{
${ }^{9}$ Tamże, s. 23.

${ }^{10} \mathrm{Za}$ : P. Czapliński, dz. cyt., s. 12.
} 
natomiast kobietom siedem razy (w tym trzy razy Tokarczuk). Oto lista laureatów i laureatek Nagrody Literackiej Nike od początku jej istnienia, z uwzględnieniem liczby nominowanych kobiet i zasiadajaccych w jury.

\begin{tabular}{|c|c|c|c|}
\hline Rok & $\begin{array}{c}\text { Liczba kobiet } \\
\text { nominowanych } \\
\text { przez jury }\end{array}$ & Nagrodzony/a & Liczba kobiet w jury \\
\hline 1997 & 5 & Wiesław Myśliwski & $1 / 9$ \\
\hline 1998 & 5 & Czesław Miłosz & $1 / 9$ \\
\hline 1999 & 3 & Stanisław Barańczak & $1 / 7$ \\
\hline 2000 & 6 & Tadeusz Różewicz & $2 / 10$ \\
\hline 2001 & 5 & Jerzy Pilch & $2 / 9$ \\
\hline 2002 & 7 & Joanna Olczak-Ronikier & $2 / 9$ \\
\hline 2003 & 6 & Jarosław Marek Rymkiewicz & $3 / 9$ \\
\hline 2004 & 7 & Wojciech Kuczok & $2 / 9$ \\
\hline 2005 & 5 & Andrzej Stasiuk & $2 / 9$ \\
\hline 2006 & 7 & Dorota Masłowska & $2 / 9$ \\
\hline 2007 & 3 & Wiesław Myśliwski & $3 / 9$ \\
\hline 2008 & 7 & Olga Tokarczuk & $3 / 9$ \\
\hline 2009 & 6 & Eugeniusz Tkaczyszyn-Dycki & $3 / 9$ \\
\hline 2010 & 9 & Tadeusz Słobodzianek & $4 / 9$ \\
\hline 2011 & 5 & Marian Pilot & $4 / 9$ \\
\hline 2012 & 11 & Marek Bieńczyk & $3 / 9$ \\
\hline 2013 & 10 & Joanna Bator & $3 / 9$ \\
\hline 2014 & 4 & Karol Modzelewski & $2 / 9$ \\
\hline 2015 & 8 & Olga Tokarczuk & $3 / 9$ \\
\hline 2016 & 11 & Bronka Nowicka & $3 / 9$ \\
\hline 2017 & 7 & Cezary Łazarewicz & $4 / 9$ \\
\hline 2018 & 8 & Marcin Wicha & $4 / 9$ \\
\hline 2019 & 7 & Mariusz Szczygieł & $5 / 9$ \\
\hline
\end{tabular}

Warto zwrócić uwagę, że kobiety zaledwie dwa razy stanowiły większość nominowanych, a jedynie raz połowę finałowej dwudziestki. Już te skrom- 
ne dane statystyczne świadczą o dyskryminacji ze względu na płeć w polu. Parytet nie obowiąuje, mimo że istnieje tendencja wzrostowa udziału kobiet wśród nominowanych - w pierwszej dekadzie funkcjonowania nagrody średnia liczba nominowanych na rok to 5,6 , a w drugiej już 7,4. Oczywistym jest, że większa liczba nominowanych kobiet oznacza zwiększenie szans na nagrodę dla kobiety, co pokazuje, że jest to kwestia zmieniających się uwarunkowań społeczno-kulturowych, a nie indywidualnych talentów.

Warto zwrócić też uwagę na genderowy podział jury, w którym widoczna jest również tendencja wzrostowa udziału kobiet, szczególnie w drugiej dekadzie istnienia nagrody, mimo że kobiety zaledwie raz stanowiły większość jury - w roku 2019. Zasadnym wobec tego będzie twierdzenie, że liczba kobiet w jury wpływa na liczbę nominowanych pisarek - zwiększa ja. Jednocześnie należy zauważyć, że nie zwiększa ich szans na otrzymanie statuetki.

Analizując inne nagrody literackie, przykładowo Paszporty Polityki, nie można zauważyć podobnych, wzrostowych tendencji - w tym konkretnym przypadku, licząc od roku 2004, gdy pojawiły się oficjalne nominacje do Paszportów (w kategorii Literatura - trzy osoby każdego roku), kobiety zostały nominowane 12 razy na 42 nominacje, natomiast nagrodę zdobyły trzy razy (Sylwia Chutnik w 2008, Natalia Fiedorczuk-Cieślak w 2016 i Małgorzata Rejmer w 2018).

\section{Umiejscowienie Joanny Bator w polskim polu literackim}

Joanna Bator: Moja koleżanka podsłuchała rozmowę na pewnej konferencji w Krakowie. Mówi jedna ważna pani profesor do ważnego pana profesora: „Ale co zrobić z tą Bator?" [...] $]^{11}$

Mimo, że Bator debiutowała w roku 2002, sytuacja w polu zmieniła się diametralnie nieco ponad 10 lat wcześniej. Jak zauważa Bourdieu w Męskiej dominacji, kobiety sa zazwyczaj związane ze sferą prywatna - domowa i reprodukcyjna - co powoduje utrwalanie patriarchalnego schematu sfery publicznej, a przez to utrzymanie niekorzystnego dla nich porządku ekonomii i sfery symbolicznej ${ }^{12}$. Pewne jest, że zmiana w obrębie państwowości, która wówczas nastapiła, wytyczyła kobietom szersze możliwości kariery, między innymi te związane $\mathrm{z}$ byciem freelancerkami, wykonywaniem wolnych zawodów - przykładowo pisarkami właśnie.

${ }^{11}$ J. Winiarski, Idealny sposób na kwietniowa noc. Rozmowa z Joanna Bator, <http:// www.literaturajestsexy.pl/idealny-sposob-na-kwietniowa-noc-rozmowa-z-joanna-bator/> [dostęp: 6.03.2019].

${ }^{12}$ P. Bourdieu, Męska dominacja, przeł. L. Kopciewicz, Warszawa 2004, s. 27. 
Najważniejszym ze skutków było dalsze eksplorowanie tematu kobiecego dorastania i poszukiwania tożsamości, a także kobiecych relacji międzypokoleniowych, czego kontynuacją są między innymi Piaskowa góra i Chmurdalia ${ }^{13}$. Dylogia ta jest saga rodzinna, której podstawę tworzy triada biografii kobiet z trzech pokoleń - Zofii, mieszkanki Polesia, która wprowadza do książki wątki wojenne i postpamięciowe, jej córki - Jadzi Chmury, która emigruje do Wałbrzycha, a większość jej życia upływa w trudach PRL-u, i wreszcie wnuczki Zofii - Dominiki, która decyduje się na opuszczenie miasta i poszukiwanie swojej tożsamości w oderwaniu od Polski, w podróży. W odniesieniu do Piaskowej góry Dariusz Nowacki zwraca uwagę, że:

[...] najważniejsza jest jej odrębność na tle dokonań polskiej prozy feministycznej. To bodaj pierwsza nasza powieść, która tak wyraźnie komplikuje problem kobiecej martyrologii. Bator - co wyjątkowe - nie proponuje swoim czytelniczkom kobiecej sztamy. Chce sprawiedliwego osądu, namawia do patrzenia prawdzie w oczy ${ }^{14}$.

W ostatnich latach XX wieku w polskim polu literackim doszło do utożsamienia literatury kobiecej z literatura popularną ${ }^{15}$. Doświadczenie męskie zostało zuniwersalizowane, a doświadczenie kobiece uznane za inne, nie-ludzkie - ograniczone wyłącznie do kobiet. W momencie opublikowania przez Bator doktoratu posługującego się metodologią krytyki feministycznej, a następnie powieści-manifestu kobieta, spór był już wyciszony, jednak pisarki wciąż wchodzą do kanonu, uzyskują autonomię w obrębie pola pomimo swojej kobiecości-jako że sama kobiecość jest słowem-kluczem do ich twórczości, lecz również - oczywistym znakiem jej niższej wartości artystycznej ${ }^{16}$. Ten mechanizm jest łatwo uchwytny, gdy przenalizuje się zmianę strategii pisarskiej, jaka nastapiła w twórczości Bator po otrzymaniu nagrody Nike a więc po tym, jak nie tylko zaznaczyła swoją pozycję w polu, ale i swoją autonomiczność. Krytyka, z jaką spotkała się pisarka ze strony uczestników gry posiadających kapitał symboliczny, jest zaskakująca, a w szczególności dotyczy to profesjonalnych komentatorów życia literackiego. Śledzić ja można w dwóch obszarach, które szczegółowo omówię: w wywiadach, jakie przeprowadzono z Bator i miażdżąco złych recenzjach pierwszej powieści wydanej po Nike, czyli Roku królika.

${ }^{13}$ Można wymienić tutaj również takie książki jak Jolanta Sylwii Chutnik, Utwór o Bogu, Matce i Ojczyźnie Bożeny Keff, Bambino Ingi Iwasiów czy Między nami dobrze jest Doroty Masłowskiej.

${ }^{14}$ D. Nowacki, Recenzja: „Piaskowa Góra” Joanny Bator, <http://wyborcza. pl/1,75517,6253476,Pia skowa_Gora_Bator_Joanna.html> [dostęp: 3.05.2019].

${ }^{15}$ M. Świerkosz, W przestrzeniach tradycji. Proza Izabeli Filipiak i Olgi Tokarczuk w sporach o literature, kanon i feminizm, Warszawa 2014, s. 177.

${ }^{16}$ Tamże, s. 178. 
Joanna Bator jako pisząca kobieta w wywiadach przeprowadzanych przez mężczyzn, często jest sprowadzana do ról biologicznych; zadawane jej pytania odnoszą się przede wszystkim do jej fizyczności i życia prywatnego. Analiza wywiadów z pisarzami pozwala mi stwierdzić, że spotykają się oni z tego rodzaju traktowaniem niezwykle rzadko, a pytania odnośnie ich fizyczności zawsze łączą się z elementami marketingowej kreacji ${ }^{17}$. Joanna Bator z czasem również podjęła grę z medialnymi oczekiwaniami wobec jej wizerunku, co z pewnością spopularyzowało jej osobę w mediach.

Jako przykład przytaczam poniżej fragment głośnego wywiadu przeprowadzonego z Bator przez Tomasza Kwaśniewskiego. Ukazał się 16 grudnia 2013 roku w numerze gwiazdkowym „Newsweeka”, tuż po otrzymaniu przez autorkę nagrody Nike i ze względu na poruszaną w nim tematykę (np. poliamorię) wywołał skandal, szereg reakcji i komentarzy w życiu literackim. Warto zwrócić również uwagę na sensualna, ilustrującą wywiad, fotografię, pochodząca z prywatnego archiwum autorki.

Joanna Bator: „Ciemno, prawie noc” wydałam w listopadzie 2012 i do lipca 2013 nie napisałam nic godnego uwagi. Pustka. Marazm. Tracenie czasu. Marcowy półmaraton pobiegłam więc w intencji ożywienia źródła.

Newsweek: A może ty biegasz, bo boisz się, że będziesz gruba?

Joanna Bator: To jest jedna z najstraszniejszych rzeczy, jakie mogłyby mnie spotkać ('smiech). I bardzo współczuję grubym ludziom, bo jest to jedna z nielicznych grup, na których opresję przyzwalamy. Jedna z najpiękniejszych dla mnie rzeczy i najbardziej seksownych to twardy płaski brzuch dowolnej płci.

\section{Newsweek: Ile ważysz?}

Joanna Bator: 52 kilo.

$[\ldots]$

\section{Newsweek: Dziecko?}

Joanna Bator: Co dziecko?

Newsweek: Chcesz mieć dziecko?

$[\ldots]$

${ }^{17}$ Na przykładach Jacka Dehnela i Michała Witkowskiego pisze o tym Dominik Antonik w swojej książce Autor jako marka: literatura w kulturze audiowizualnej społeczeństwa informacyjnego, Kraków 2014. 


\section{Newsweek: Nie używasz antykoncepcji?}

Joanna Bator: Lubię ryzyko, ale żeby aż tak? Chodzi mi raczej o to, że może już pora, by kimś się zaopiekować. Oddać to dobre, co dostałam w życiu. Stworzyłam w „Ciemno, prawie noc” bohaterkę, która zaopiekowała się obcym, skrzywdzonym dzieckiem. I chyba na razie tylko na tyle mnie stać w kwestii rozmnażania ${ }^{18}$.

Z powyższego tekstu wyłania się kilka interesujących faktów: pierwszym z nich jest kontekst wywiadu, który powstał po otrzymaniu przez Bator Nike, co czytamy w lidzie. Wywiad skupia się jednak w dużej mierze na życiu prywatnym autorki, co samo w sobie nie jest złe, a wręcz przeciwnie - niezwykle interesujące. Smuci natomiast obecność i nachalność pytań o macierzyństwo. Sprowadzenie piszącej kobiety wyłącznie do sukcesów prokreacyjnych (lub ich braku), a także do ciała (znowu - atrakcyjnego i seksualnego bądź nie) jest standardowa praktyka patriarchalnego dyscyplinowania kobiet. Dziennikarz kilkakrotnie powraca do tematu bezdzietności autorki, mimo że otrzymuje raczej wyczerpujące odpowiedzi na każde z nich. Interesująca jest również jedna z wypowiedzi autorki, dotycząca tego tematu: „[...] urodziłam tyle dzieci w swoich książkach”. Pytania podobnego rodzaju pojawiaja się w wywiadzie przeprowadzonym przez Romana Pruszyńskiego dla portalu polki.pl:

RP: Dom kojarzy się z gniazdem, a w gnieździe...

Joanna Bator: Składa się jaja?

\section{RP: Rozumiem, że ta sfera Ciebie nie dotyczy?}

Joanna Bator: Długo myślałam - do 35. roku życia - że jestem kobieta, która w pewnym momencie będzie chciała mieć dziecko. Przyjdzie taki moment, że powiem: „Chcę i już! Teraz!”. Znam z opowieści, że potrafi to być tak obezwładniające pragnienie, że nieważne, czy jest właściwy mężczyzna, dom, pieniądze. Czekałam, aż to przyjdzie. Rozpoznałabym, bo wiem, co znaczy pragnąć czegoś.

\section{RP: Przyszło, ale nie było Cię w domu?}

Joanna Bator: Najbliżej chęci posiadania dziecka byłam w Nowym Jorku, gdy nie wiedziałam, co zrobić ze swoim życiem. Ale pragnienie nie przyszło. Nie chcę dzieci, jednak wszystkie babskie atawizmy mam na miejscu. Nadal mnie ekscytuje, jak dziewuszkę, kiedy mężczyzna na etapie pierwszej fascynacji mówi: „Ach, mieć z tobą dziecko!”. Opowiedziałam to przyjaciółce: „Bożena, przecież za rok, dwa, gdy ktoś

${ }^{18}$ T. Kwaśniewski, Joanna Bator. Jestem nienażyta, „Newsweek” 2013, 16-29.12, nr $51 / 52$. 
tak powie, to stanie się żenujące”. A ona na to: „Nie chcę cię martwić, Joasiu, ale oni wkrótce przestaną to mówić".

\section{RP: Czekasz na to?}

Joanna Bator: A skąd. To będzie wejście w wiek średni. Na szczęście urodziłam tyle dzieci w swoich książkach.

\section{RP: „Ciemno, prawie noc” kończy się tak, że bohaterka bierze dziewczyn- kę z domu dziecka.}

Joanna Bator: Nigdy o tym nie myślałam. Chociaż nie, nie jestem do końca szczera. Czasem myślę, że może czas odwdzięczyć się losowi za tyle dobrych rzeczy. Może właśnie zaopiekować się kimś? Mówili mi panowie z jury Nike, że chcieliby poznać dalsze losy Alicji i tej dziewczynki. Ale, niestety, na dziś chyba tylko tyle potrafiłam zrobić dla tego dziecka. Uratować je, dalej niech sobie gówniarz sam radzi ${ }^{19}$.

Już sam ten fragment ukazuje, że problematyzacja macierzyństwa w odniesieniu do kobiet wykonujacych wolne zawody (tutaj: pisarek), wyłamujących się ze schematu standardowej, przygotowanej przez patriarchalne społeczeństwo drogi życiowej, nie jest niczym nowym. Również pytania o wage i stosowanie antykoncepcji zdają się być wątpliwie umocowane w toku rozmów. Ważny jest jednak sposób, w jaki sposób autorka odpowiada, z jaką stanowczością dookreśla swoją wolę (przykładowo: „Rozpoznałabym, bo wiem, co znaczy pragnąć czegoś”). W przeciwieństwie również do wcześniej udzielanych wywiadów, pisarska wprost odpowiada na pytania dotyczące życia prywatnego, relacji z partnerem itp. Stanowi to element zmiany jej strategii autokreacji.

Świadomość kobiecości ,jako formy kulturowej i konstrukcji psychicznej opartej na dominacji tego, co widać, na prezentacji siebie jako wygladu"20 podporządkowanej męskiemu pożądaniu pojawia się we wszystkich jej powieściach ${ }^{21}$, jednak to po otrzymaniu nagrody Nike następuje mo-

${ }^{19}$ R. Pruszyński, Poruszajacy wywiad z Joanna Bator. O życiu w Japonii, nieudanym zwiazku i nagrodzie Nike, <https://polki.pl/zycie-gwiazd/newsy,poruszajacy-wywiad-z-joanna-bator,10036723,artykul.html> [dostęp: 16.04.2019].

${ }^{20}$ U. Chowaniec, „Femme mélancolique”, czyli o pesymizmie najnowszej literatury kobiecej, [w:] Ćwiczenia z rozpaczy. Pesymizm w prozie polskiej po 1985 roku, red. J. Jarzębski, J. Momro, Kraków 2011, s. 395.

${ }^{21}$ „Zrób decydujacy krok w walce ze starzeniem się skóry. Jak pokonać niechęć wobec seksu oralnego? Chroń swoje usta. Pomoże im delikatna maseczka. Pochyl głowę i zamknij oczy. Zrób to dla swoich rzęs. Ruszaj do walki ze skórką pomarańczową. [...] Nanocząsteczka czystej witaminy E przywróci ci młodość. A oczy nabiorą blasku. [...] Postaw na styl romantyczny. Usta, którym żaden mężczyzna się nie oprze. Oto absolutna kobiecość”. J. Bator, kobieta, Warszawa 2002, s. 15-16. 
ment, w którym Joanna Bator zaczyna bardzo świadomie swój wizerunek kształtować, grać w maskaradę ${ }^{22}$, rysuje się to niezwykle wyraźnie w jej wypowiedziach odnośnie do pisarskich obyczajów. Przykładowo opisuje strój, o którym pisze:

To lekkie kimono codzienne uszyte z bawełny, czyli jukata. Kiedy jest chłodniej, zakładam na nie jedwabne haori. Ma podobny kształt, tylko jest krótsze, sięga do bioder. Jukata jest równie wygodna jak dres, ale o wiele ładniejsza. Z pięknych rzeczy buduję swoją niszę, umacniam jej mury ${ }^{23}$.

Mimo że elementy transgresyjne znajdują się w każdej z książek (sztandarowym przykładem jest tu tabu wykorzystywania seksualnego dzieci i handlu nimi w Ciemno, prawie noc), to przekroczenie nigdy nie następuje w pełni. Sytuuje to prozę Joanny Bator w opozycji do bardziej radykalnych propozycji feministycznych autorek, święcących triumfy i upadki w latach dziewięćdziesiątych (Iwasiów, Filipiak, Gretkowska, Goerke itd.), a zbliża do prozy feminizmu liberalnego, mainstreamowego, prozy feminizującej, a nie feministycznej, literatury kontestującej, a nie radykalnie zmieniającej. Kobieta w prozie Bator jest abiektem ${ }^{24}$, który na sposób liberalny wyzwala się sam. Niemal wszystkie główne bohaterki powieści Bator są osobami z wysokim kapitałem kulturowym i społecznym, przypominające fizycznie i wiekowo autorkę. Bator w kobiecie pisze:

[...] zegar biologiczny [kobiety po trzydziestym roku życia - przyp. A.K.] zmienia się wówczas [...] w zegar z kukułką powtarzająca co pół godziny jedno z tysiąca społecznych oczekiwań. Bądź młoda. Niepomarszczona. Szczupła. Zamężna. Miej dziecko. Miej dziecko. Miej dziecko ${ }^{25}$.

W tym miejscu przytoczyć warto również fragment wywiadu udzielonego Katarzynie Marcysiak w cyklu Kultowe rozmowy:

W tym momencie życia interesuje mnie to jak żyć, co z miłościa, jak można stwarzać miłosne związki, z takiego miejsca w jakim ja jestem - podmiotowego, artystka, pisarka, feministka, osoba, która zawsze prowadziła jednak życie dość niekonwencjonalne, z małą inklinacja, delikatnie mówiąc, do tradycyjnego życia rodzinnego. [...] I jedna z tych rzeczy jest raczej poliamoria. [...] Mam w sobie motyw taki bardziej patriarchalny - kobieta stoi na balkonie i na coś czeka. I tylko, że patrzy jak

22 J. Riviere, Womanliness as a masquerade, „The International Journal of Psychoanalysis" 1929, nr 10, s. 303-313.

${ }^{23}$ D. Wodecka, Bator: Moje przykazania od III do X, <http://wyborcza.pl/magazyn/1,124059,12782963,Bator_Moje_przykazania_od_III_do_X.html> [dostęp: 14.07.2019].

${ }^{24}$ J. Kristeva, Potęga obrzydzenia. Esej o wstręcie, przeł. M. Falski, Kraków 2007, s. 7-9.

${ }^{25}$ J. Bator, kobieta..., s. 150. 
dwóch mężczyzn idzie sobie pobiegać jedną z moich ukochanych dróg biegowych na mojej wyspie greckiej $[\ldots]^{26}$.

Jak wspomniałam wcześniej, Joanna Bator rozpoczęła pisanie swojej debiutanckiej powieści tuż po opublikowaniu doktoratu, pisanego w duchu feminizmu i omawiającego dzieła twórczyń écriture féminine w duchu psychoanalizy. Powieści Bator - co zauważyła Agnieszka Gajewska - można wpisać z tego powodu w nurt powieści akademickiej, jako że znajdujemy w nich odzwierciedlenie zainteresowań badawczych, a sama autorka korzysta z całego instrumentarium tej metody również w pisarstwie fikcyjnym ${ }^{27}$. Równocześnie, nie bez szczypty ironii, mówi:

Mam raczej takie refleksje ogólne związane z faktem, że jestem i będę wszywana w nurt kobiecy/feministyczny. To budzi we mnie ambiwalentne uczucia - z jednej strony jestem za, bo nie mam nic przeciw ani kobietom, ani feminizmowi, z drugiej irytuje mnie, że literatura $\mathrm{z}$ dominującymi bohaterami męskimi jest po prostu literatura, a ta, w której na plan pierwszy wysuwają się bohaterki - jest kobieca. Zapraszana jestem na spotkania pt. „Babskie gadanie”, „Czy proza jest kobieta??” No więc czasem sobie myślę, że spróbuje tak dla sprawdzenia, czy potrafię, napisać coś z narratorem męskoosobowym, z głównym bohaterem męskim taką męską męskością jak jaki Hemingway. Myślę, wymyślam, już jakaś historia się kroi i widzę, że ten mój męski bohater jakoś się tak przegina, w lustro zerka i tak, on najbardziej to by chciał zmienić płeć albo pojechać na wczasy do Lubiewa ${ }^{28}$.

Nie niosę żadnego sztandaru. W żaden już nie wierzę. Nie walczę w imię jakieś metanarracji. Trzeba uprawiać swój ogródek i próbować zapobiegać okrucieństwu. Świadomie oczywiście odwołuję się tu do Woltera i Rorty'ego. Jeśli ma się na to siłę, jest to siła, by pisać. Większość ludzi ma literaturę w nosie, ale dla tych, którzy czytaja - warto. Wszystkie spotkania z czytelnikami przekonują mnie do tego, że jest się z kim komunikowaćéc.

Z jednej strony sama przyznaje, że etykietka feministki/pisarki kobiecej ją irytuje (co jeszcze bardziej zbliża ją do pisarek ecriture féminine, zwłaszcza do Cixous), wyrażając swoją opinię na temat jednego ze współczesnych dylematów feminizmu, tj. zamykania się feministek w kobiecych

${ }^{26}$ K. Marcysiak, dz. cyt.

${ }^{27}$ A. Gajewska, Miłość $w$ czasach patriarchatu. Proza feministyczna wobec konwencji romansu i melodramatu na przykładzie „Bambino” Ingi Iwasiów i „Piaskowej góry” Joanny Bator, [w:] Miłość we wspótczesnych tekstach kultury, red. M. Szczepaniak, Bydgoszcz 2010, s. 83-84.

${ }^{28}$ J. Winiarski, dz. cyt.

${ }^{29}$ A. Wienias, Interesuje mnie przede wszystkim opowiadanie ciekawych historii, <http:// fraza.univ.rzeszow.pl/numer/85-Rozmowa-z-Joanna-Bator.php> [dostęp: 5.06.2019]. 
„gettach”, czy też mówiąc językiem mniej nacechowanym - w lewicowych bańkach informacyjnych. Jednocześnie zdaje sobie dogłębnie sprawę z niemożności ucieczki przez kwestiami genderowymi, a nawet z niemożności niekobiecego pisania, pisania niewywodzącego się z doświadczenia ciała, co powoduje swoisty konflikt tragiczny. W cytowanym wywiadzie wypowiada się dalej:

Nie mam predyspozycji na działaczkę $\mathrm{w}$ tym sensie, że nigdy nie wdam się w politykowanie i przynależność partyjna, ale gdy na spotkaniu autorskim na przykład w Grudziądzu mówię: ,jestem feministką", to mam wrażenie, że robię dobrą robotę. Pokazuję, że jesteśmy różne, że w ramach feminizmu funkcjonują różne modele kobiecości i że stereotyp feministki jest właśnie tym - stereotypem ${ }^{30}$.

Stanowi to przykład bardzo indywidualistycznego i liberalnego podejścia do feminizmu. Warto zwrócić uwagę, że pokazywanie modelu kobiecości zdecydowanie uprzywilejowanej (normatywnie atrakcyjna - szczupła, z długim włosami, wysoka, biała - intelektualistka z klasy średniej, z Warszawy, w dodatku wyzwolona seksualnie artystka) jako wzorca feministki, wcale nie przybliża feminizmu przeciętnemu odbiorcy czy odbiorczyni z Grudziadza i zastępuje jeden stereotyp innym. Podejście to niejako potwierdzają fragmenty rozmowy przeprowadzonej na użytek publikacji Pod podszewka. Prawdziwy wizerunek pisarza, gdzie mówi:

Piękno ciała mnie pociaga, nie wyobrażam sobie erotycznego zauroczenia człowiekiem, który nie ma sportowego ciała. To na pewno wykluczajaca postawa i dla wielu niezbyt miła, ale erotyka nie podlega zasadom równości, a piękno bywa okrutne, bo nie ma go bez brzydoty ${ }^{31}$.

Biorac pod uwagę, że jeszcze kilka akapitów wcześniej Bator wspominała o seksualizacji ciała i piękna kobiet w kulturze, zdaje się to nie tylko wykluczające (fatshamingowe), ale również zwyczajnie niespójne z jej samoświadomymi deklaracjami, jednocześnie kończącze wypowiedź w sposób uniwersalizujacy zagadnienia związane z estetyką ciała. Zaledwie dwie strony później pojawia się fragment wypowiedzi jednej z autorek książki, przytaczającej rozmowę, która przeprowadziła z Bator:

Joanna Bator zauważa, że istnieje dziś bogactwo trendów, które rzadko widać na młodziutkich kobietach. Dziewczyny są dziwnie zuniformizowane, noszą dżinsy

\footnotetext{
${ }^{30}$ J. Winiarski, dz. cyt.

${ }^{31}$ Z. Karaszewska, S. Stano, Wizualna strona istnienia, [w:] Pod podszewka. Prawdziwy wizerunek pisarza, Warszawa 2018, s. 67.
} 
rurki, airmaxy, tiszerty. Wyróżnianie się nie jest dla nich wartością. Gdyby mogła, pisarka ubrałaby te dziewczyny inaczej ${ }^{32}$.

Z wypowiedziach tych razi kontrast świadomości względności sądów i upodobań z próbą normatyzacji ciała, erotyki, wyglądu zewnętrznego innych osób. Autorka replikuje w ten sposób opresyjne kanony urody zwiąane z patriarchatem: seksualność jest wspierana tylko wówczas, gdy wpisuje się w kanony wysportowanego piękna, co znów nasuwa skojarzenie z feminizmem liberalnym - postulującym raczej standaryzację i dopasowanie jednostek do wymogów społecznych, a nie socjalnym, zaangażowanym walczącym o wyzwolenie $\mathrm{z}$ opresyjnego kanonu. Zdziwienie budzić może również wypowiedź autorki mówiąca o uniformizowaniu młodych kobiet, które być może zmęczone są również narzucaniem im, jak mają wyglądać zarówno przez patriarchat, jak i media. W tym momencie warto przytoczyć fragment kobiety, w której to sama Bator burzy się przeciwko narzucaniu wizji wyglądu młodym kobietom:

Cała jestem w falbankach. Oto twój styl. [...] Zrób decydujący krok w walce ze starzeniem się skóry. [...] Postaw na styl romantyczny. Usta, którym żaden mężczyzna się nie oprze. Oto absolutna kobiecośćc ${ }^{33}$.

W innej, o kilka miesięcy nowszej publikacji, czyli Własnym pokoju, Bator z kolej wypowiada się w zgoła inny sposób, niejako przyznając się do własnego uprzywilejowania, co również stanowi zmianę:

[...] Teraz widzi, że nie każdy jest się w stanie wyzwolić, nie ze wszystkiego, nie od razu. Czasem w ogóle. [...] Myślę, że przez prawie dwie dekady zaangażowania $\mathrm{w}$ feminizm żyłam z optymizmem i wiarą w ruch emancypacyjny. [...] z perspektywy mojej społecznej bańki i poglądów politycznych dookoła widziałam postęp, przyrost możliwości dla kobiet. I owszem, polepszył się los kobiet, ale tylko pewnej grupy, która miała dostęp do tych możliwości. Większość kobiet waliła głową w szklany lub betonowy sufit [...]. Tymczasem pierwszy krok do emancypacji to zdanie sobie sprawy, że jest się ofiarą ${ }^{34}$.

\section{Zakończenie}

Joanna Bator weszła w pole literackie z uprzywilejowanej pozycji, na którą miało wpływ kilka czynników - z jednej strony należało do nich wy-

${ }^{32}$ Tamże, s. 70.

${ }^{33}$ J. Bator, kobieta..., s. 16.

${ }^{34}$ J. Bator, K. Sulej, Pokój z widokiem, [w:] Wtasny pokój, Virginia Woolf, przeł. A. Graff, Warszawa 2019, s. 40. 
kształcenie autorki i wcześniejsze poruszanie się po obrzeżach pola jako akademiczki (stąd przykładowo znajomość z krytykami, którzy później recenzowali jej książki, łatwiejszy dostęp do mediów, wydawnictw), z drugiej moment debiutu, tj. po ugruntowaniu się kobiecej powieści inicjacyjnej w latach dziewięćdziesiątych ubiegłego wieku. Jednak mieszkanie poza granicami kraju, które uniemożliwiało literalny udział w życiu literackim, jak również aspekt genderowy, wytworzyły sytuację zmiennej recepcji jej książek, jak również dwuadresowość kreacji medialnej.

Bator, która w początkowym okresie swojej twórczości, a szczególnie w czasie wydawania tzw. trylogii wałbrzyskiej, zaliczana była do twórców literatury wysokiej, po otrzymaniu nagrody Nike w 2013 roku, zmieniła styl pisania, jak również swój autorski image, co spowodowało przeniesienie jej powieści w odbiorze krytycznym do literatury popularnej. Można zakładać, że otrzymanie nagrody Nike zmieniło jej miejsce w polu literackim w wielu aspektach - co najważniejsze, stała się wówczas twórczynią doceniona, zauważona, już nie początkujacca. Właśnie to ugruntowanie pozycji pisarskiej w polu doprowadziło do zmiany jej strategii medialnej, pozornego odsłonięcia się i opowiedzenia mediom o sobie. Odnieść można wrażenie, że ta zmiana, którą z perspektywy krytycznej postrzegać można jako negatywna (obniżenie rejestru wytwarzanej sztuki), paradoksalnie wyemancypowała ja literacko i pozwoliła na tworzenie narracji w innej niż dotychczas konwencji.

\section{BIBLIOGRAFIA}

Antonik D., Autor jako marka: literatura w kulturze audiowizualnej społeczeństwa informacyjnego, Kraków 2014.

Barrie J.M., Piotruś Pan w Ogrodach Kensingtońskich, przeł. A. Wieczorkiewicz, Poznań 2018.

Bator J., Sulej K., Pokój z widokiem, [w:] Własny pokój, Virginia Woolf, przeł. A. Graff, Warszawa 2019.

Bourdieu P., Męska dominacja, przeł. L. Kopciewicz, Warszawa 2004.

Bourdieu P., Reguty sztuki, przeł. A. Zawadzki, Kraków 2001.

Chowaniec U., „Femme mélancolique”, czyli o pesymizmie najnowszej literatury kobiecej, [w:] Ćwiczenia z rozpaczy. Pesymizm w prozie polskiej po 1985 roku, red. J. Jarzębski, J. Momro, Kraków 2011.

English J.F., Ekonomia prestiżu, przeł. P. Czapliński, Ł. Zaremba, Warszawa 2013.

Gajewska A., Miłość w czasach patriarchatu. Proza feministyczna wobec konwencji romansu i melodramatu na przykładzie „Bambino” Ingi Iwasiów i „Piaskowej góry” Joanny Bator, [w:] Miłość we wspótczesnych tekstach kultury, red. M. Szczepaniak, Bydgoszcz 2010.

Jankowicz G. i in., Literatura polska po 1989 roku w świetle teorii Pierre’a Bourdieu. Raport z badań, Kraków 2014. 
Kristeva J., Potęa obrzydzenia. Esej o wstręcie, przeł. M. Falski, Kraków 2007.

Lunnemann P., Jensen M.H., Jauffred L., Gender bias in Nobel Prizes, „Humanities \& Social Sciences Communication” 2019, nr 5, <https:/www.nature.com/articles/ s41599-019-0256-3> [dostęp: 30.04.2021].

Riviere J., Womanliness as a masquerade, „The International Journal of Psychoanalysis” 1929, nr 10, s. 303-313.

Świerkosz M., W przestrzeniach tradycji. Proza Izabeli Filipiak i Olgi Tokarczuk w sporach o literature, kanon i feminizm, Warszawa 2014.

CYTOWANE WYWIADY I RECENZJE

Karaszewska Z., Stano S., Wizualna strona istnienia, [w:] Pod podszewka. Prawdziwy wizerunek pisarza, Warszawa 2018.

Kwaśniewski T., Joanna Bator. Jestem nienażyta, „Newsweek” 2013, 16-29.12, nr 51/52.

Marcysiak K., Kultowe rozmowy: Joanna Bator, <https://www.youtube.com/watch?v=3HY5GH8HAm8> [dostęp: 5.01.2019].

Nowacki D., Recenzja: „Piaskowa Góra” Joanny Bator, <http://wyborcza. pl/1,75517,6253476,Pia skowa_Gora_Bator_Joanna.html> [dostęp: 3.05.2019].

Pruszyński R., Poruszajacy wywiad z Joannq Bator. O życiu w Japonii, nieudanym zwiazku i nagrodzie Nike, <https://polki.pl/zycie-gwiazd/newsy,poruszajacy-wywiad-z-joanna-bator, 10036723,artykul.html> [dostęp: 16.04.2019].

Światynia Nike. Wywiad z Joanna Bator, [w:] Rozmowy z autorami-lubimyczytac.pl, pod red. D. Warszawskiego, J. Janowicz, <https://issuu.com/lubimyczytac.pl/docs/ rozmowy_z_autorami_-_lubimyczytac.p> [dostęp: 5.06.2019].

Wienias A., Interesuje mnie przede wszystkim opowiadanie ciekawych historii, <http:// fraza.univ.rzeszow.pl/numer/85-Rozmowa-z-Joanna-Bator.php> [dostęp: 5.06.2019].

Winiarski J., Idealny sposób na kwietniowa noc. Rozmowa z Joannq Bator, <http://www. literaturajestsexy.pl/idealny-sposob-na-kwietniowa-noc-rozmowa-z-joanna-bator/> [dostęp: 6.03.2019].

Wodecka D., Bator: Moje przykazania od III do X, <http://wyborcza.pl/magazyn/1,124059,12782963,Bator_Moje_przykazania_od_III_do_X.html> [dostęp: 14.07.2019].

Agnieszka Kocznur - mgr, doktorantka w Instytucie Filologii Polskiej Uniwersytetu im. Adama Mickiewicza w Poznaniu, a także członkini Zespołu ds. Badań nad Literatura i Kultura Dziecięca, tłumaczka. Jej zainteresowania badawcze obejmuja gender studies, literaturę dla młodzieży i nowe media. ORCID: 0000-0002-7510-6956. E-mail: <agnieszka.kocznur@gmail.com>.

Agnieszka Kocznur - MA, PhD student at the Institute of Polish Philology at Adam Mickiewicz University in Poznan, member of the Children's Literature and Culture Research Team, translator. Her research interests include gender studies, YA literature and new media. ORCID: 0000-0002-7510-6956. E-mail:<agnieszka.kocznur@gmail.com>. 
